\title{
SOME BIOCHEMICAL AND HAEMATOLOGICAL STUDIES IN BRUCELLOSIS INFECTED BUFFALOES, COWS AND SHEEP IN EL-SHARKIA GOVERNORATE
}

\author{
Aida, M. Amin", Amal, M. Hosny" and Nadia A.A. Shalabi* \\ * Biochemistry Dept., Animal Health Research Institute, Dokki. \\ *** Brucella Dept., Animal Health Research Institute, Dokki.
}

\begin{abstract}
Blood samples from 351 buffaloes, 149 cows and 551 sheep were taken from a farm at New Salhia, (El-Sharkia Governorate) and examined for the incidence of brucellosis by the following serological tests, qualitative buffered acidified plate antigen (BAPAT), Rose Bengal Plate test (RBPT), the standard quantitative tube agglutination test (SAT) and the confirmatory quantitative complement fixation test (CFT). Biochemical and haematological studies were done on 60 seropositive (20 from each species) as well as 60 seronegtaive animals (20 from each species) as control ones

The bioechmiacl analysis revealed a significant increased enzymatic activities for both, asparatate aminotransferase (AST) and alanine aminotransferase (ALT), and a significant increase in urea level of infected animals as compared with the control ones. On the other hand, a significant decrease was recorded in total serum protein and glucose levels in all infected species. Serum iron level showed a significant decrease in infected cows only. Whereas, no changes were detected for both serum calcium and inorganic phosphorus levels in infected animals comparing with control ones.

Concerning haematological profile, we recorded a significant decrease in $\mathrm{Hb}$ and $\mathrm{PCV} \%$ in all infected species accompanied with a general decrease in RBCs count, only of significant value in infected cows. The WBCs count showed insignificant alterations in all infected animals compared with control ones.
\end{abstract}




\section{INTRODUCTION}

Brucellosis species are recognized as potential agricultural, civilian and bioterrorism agents. The genus Brucella consists of at least six species, diagnosed on the basis of host preference, antigenic and biochemical characteristics as Brucella melitensis (goats and sheep), Brucella abortus (cattle and buffaloes), Brucella suis (pigs), Brucella canis (dogs), Brucella ovis (sheep) and Brucella neotomae (wood rats). Brucella abortus, Brucella melitensis and Brucella suis can infect humans with similar serious disease sequences (Pappas et al., 2006). Recently, Brucella spp. have been isolated from marine mammals and are infectious for humans (Cloeckaert et al., 2003).

Brucella spp. are primarily infect the reproductive organs and thrives in the uterus of pregnant animals, often leading to abortion late in gestation. The organism can remain undetected for prolonged periods as there are no clinical signs until abortion occur. At the time of abortion, there is a massive excretion of Brucella organisms leading to heavy environmental contamination that can result in rapid spread throughout a herd or flock (Merck Veterinary Manual, 2003).

Brucellosis is considered as one of the most serious diseases in Egypt reducing animal reproductively and productivity $(\boldsymbol{F A O}, 2003)$, and also perform a public health problem causing undulant fever(Sauret and Vilisova, 2002).

Successful control of disease needs an efficient diagnostic methods (Montaser et al., 2001). Several researches have been conducted on the diagnosis of brucellosis among animals using different serological tests, however, the real incidence of brucellosis in many countries is so difficult to be determined due to several factors one of which, is specificity and sensitivity of the variation in employed tests (Alton et al., 1988; Hosein et al., 1999 and Nielsen, 2002). 
Brucella melitensis biovar 3 is considered the prevalent type affecting cattle in Egypt (Hosein et al., 2001; El-Diasty, 2004 and Hend, 2004).

Infection with brucellosis revealed alterations in blood picture profile (Crosby et al., 1984), major elements (Nada et al., 1992) as well as serum enzyme activities (El-Sawalhy et al., 1996 and Fahmy and Hoda, 2006).

So, the target of this work is to study the biochemical and haematological changes during brucellosis in different animals (buffaloe, cows and sheep) in El-Sharkia Governorate in a trial to elucidate the pathogenesis of the adverse effects associated with brucellosis.

\section{MATERIAL AND METHODS}

\section{1- Animals:}

A total of 351 buffaloes, 149 cows and 551 sheep in a farm at New Salhia, an area with history of brucellosis in El-Sharkia Governorate were involved in this investigation. Careful clinical examination of both diseased and healthy animals was carried out according to Radostits et al. (2007). Animals were free from external and internal parasites.

Blood samples were collected by jugular vein puncture from all tested animals in two portions of clean and sterile tubes, $1^{\text {st }}$ portion collected on heparin as anticoagulant for haematological examination. The $2^{\text {nd }}$ portion collected in a clean centrifuge tube, left 10 minutes for clot, then centrifuged at $3000 \mathrm{rpm}$ for 15 minutes, separated the clear supernatant clear serum and kept in aseptic dry vial at $-20^{\circ} \mathrm{C}$ till serological and biochemical analysis. 


\section{Serological examination:}

All serum samples were tested for the presence of Brucella antibodies by a battery of serological tests. These included the screening qualitative buffered acidified plate antigen (BAPAT) and Rose-Bengal plate (RBPT). The standard quantitative tube agglutination (SAT) and finally the confirmatory quantitative complement fixation test (CFT) all according to the OIE recommendations $(\boldsymbol{O I E}, 2008)$ to correctly classify animals as negative or positive.

The antigens used in serological tests except the CFT were obtained from the Veterinary Serum \& Vaccine Research Institute, Abbassya, Cairo, Egypt. Antigen for the CFT was obtained from the National Veterinary Services Laboratories (NVSL), Ames, IA 50010, USA.

Other reagents for serological tests were prepared at the Brucella Department, Animal Health Research Institute, Dokki, Giza, Egypt.

Table (1), summarize methods used for biochemical and haematological analysis.

Table (1): Methods adopted for determination of biochemical and haematological parameters.

\begin{tabular}{|c|c|}
\hline Parameter & Author \\
\hline 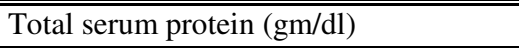 & Henry et al. (1974) \\
\hline Alanine aminotransferase activity $(\mathrm{u} / \mathrm{l})$ & Reitman and Frankel (1957) \\
\hline Aspartate aminotransferase activity (u/l) & Reitman and Frankel (1957) \\
\hline Glucose (mg/dl) & Trinder (1969) \\
\hline Urea $(\mathrm{mg} / \mathrm{dl})$ & Patton and Crouch (1977) \\
\hline Calcium (mg/dl) & Glinder and King (1972) \\
\hline Inorganic phosphorus (mg/dl) & Pasquinelli (1979) \\
\hline Iron $(\mu \mathrm{g} / \mathrm{dl})$ & Varely (1976) \\
\hline Red blood cell count $\left(\times 10^{6} / \mathrm{cm}^{3}\right)$ & Schalm (2000) \\
\hline Haemoglobin $(\mathrm{gm} / \mathrm{dl})$ & Coles (1986) \\
\hline Packed cell volume (PCV\%) & Thompson (1980) \\
\hline White blood cells $\left({\left.\mathrm{x} 10^{3} / \mathrm{cm}^{3}\right)}^{3}\right.$ & Schalm (2000) \\
\hline
\end{tabular}

Statistical analysis: Data obtained were statistically analyzed using student t-test according to SPSS 14 (2006). 


\section{RESULTS AND DISCUSSION}

Diagnosis of brucellosis in different countries of world including Egypt depends mainly upon the application of different serological tests. The importance of disease refers to its effects on animal production and reproduction.

The definitive diagnosis of brucellosis requires isolation, identification and typing of the organism. For practical purposes, the application of serological tests somewhat substitute for the time, effort and proficiency demanding bacteriological examination, using a standard confirmatory test that achieves maximum balance between sensitivity and specificity (Alton et al., 1988). The CFT was used as a substitute for bacteriology. In this study, number of 115 out of 351 buffaloes, 122 out of 149 cows and 104 out of 551 sheep from known infected herd/flock were proven positive by the confirmatory CFT. The collective results of serological examination revealed in tables (2 to 4). The control group from known brucella free areas passed the screening BAPAT and RBPT as well as the quantitative SAT.

\section{Biochemical analysis (Table, 5):}

Edward (1997) recorded that brucella are facultative intracellular pathogens with a great affinity to localize in organs rich in elements of reticuloendothelial system such as lymph nodes, spleen, bone marrow and liver.

As the organism localized in the liver, it affects its function revealing a high significant hypoproteinemia in infected buffaloes, cows and sheeps. Similar results were detected in brucella infected camel by Omaima $\boldsymbol{e t}$ al. (2003) and El-Boshy et al. (2009). 
This reduction in total protein level may be ascribed to the hepatic damage caused by brucellosis (Abu Damir et al., 1989), that damaged hepatocytes are no longer able to synthetize protein (Coles, 1986).

The damage effect of brucellosis on hepatocytes was also admitted by Montasser (1995); Forbes et al. (1996) and Enany et al. (1997) who recorded degenerative changes in the form of vacular degeneration and coagulative necrosis.

Moreover, it was recorded a highly significant increase in both ALT and AST activities, in the 3 infected species (Table, 5) which came in accordance with the results obtained by Enany et al. (1997), Helal and Abdel Fattah (2003); Helal et al. (2004) in infected sheep and Omaima et al. (2003); Fahmy and Hoda (2006) and El-Boshy et al. (2009) in infected camels. These disturbances in transmaminases activities were explained by Helal and Abd-el Fattah (2003) whom recorded that brucellosis induced activation of oxidative and phosphorylation enzymes (NAD N- Diaphorase, LDH-ase and ATPase) in liver mitochondria inducing liver dysfunction.

At the same time, our results revealed a significant decrease $(\mathrm{P}<0.05)$ in serum glucose levels of infected animals (Table, 5). This result is in agreement with that obtained by Enany et al. (1997) in infected cattle and sheep, as well as infected camels (El-Boshy et al., 2009). This decrement could be attributed to the depressed metabolic processes (Coles, 1986 and Duncan and Prasse, 1986).

Moreover, levels of serum urea of diseased buffaloes, cows and sheep showed a highly significant increase $(\mathrm{P}<0.001)$ if compared with control ones. Same results were found in brucella infected camels (Omaima et al., 2003). Such effect could be a reflection of increased protein catabolism and decreased renal flow associated with bacterial infection (Radostits, 2007). 
Concerning serum calcium and inorganic phosphorus, there were a non insignificant decrease in the levels of both elements were recorded. Similar findings were recorded in buffaloes, cows and camel (Nada et al., 1992 and Omaima et al., 2003). The insignificant decrease of serum calcium and inorganic phosphorus may be referred to the change of $\mathrm{pH}$ value in the small intestine, which hinder the absorption of calcium and phosphorus (Radostits et al., 2007).

It has been previously proved that, the ability of the invading bacteria to grow and multiply, depends on availiability of iron (Jurado, 1997). So, in anaemia of inflammatory disease the body responds by decreasing iron reutilization through increasing iron delivery to macrophages and increasing synthesis of ferritin (iron storage molecule), as well as reducing iron absorption from the intestinal tract by decreasing synthesis of transferrin (Waner and Harrus, 2000). In accordance our study showed a general reduction in serum iron levels but only of significant value $(\mathrm{P}<0.05)$ in case of infected cows, compared with the other two species. Similar results were obtained by Nada et al. (1992) and Omima et al. (2003) in brucella infected camels.

\section{Haematological examination (Table, 6):}

Brucella induced a multifactorial anaemia attributed to hypersplenism and bone marrow involvement (Pappas et al., 2006).

It was stated that bacterial lipopolysaccharides released from disrupted bacteria are readily adsorbed onto erthythrocyts and the subsequent immune response against the bacterium and its products results in erythrocyte destruction (Tizard, 1992). 
Brucellosis induced anaemia recorded in our study showed a significant decrease in $\mathrm{RBCs}$ count $(\mathrm{P}<0.05)$ in infected cows only accompanied by significant reduction in $\mathrm{Hb}$ and $\mathrm{PCV} \%$ in accordance with $\boldsymbol{E l - B o s h y}$ et al. (2009). Waner and Harrus (2000) stated that the effects on erythropoiesis in anemia of inflammatory diseases fall into 3 categories: inappropriately low erythropoietin secretion, diminished marrow response to erythropoietin and iron limited erythropoiesis.

In a recent study, Erdogan et al. (2007) reported that the experimental infection of $B$. meltinesis induced lipid peroxidation and stimulated IL-10 transcription in rat spleen. The role of brucella induced release of inflammatory cytokines on decreasing erythropoiesis was previously recorded by Stevens and Olsen (1994) and admitted by Odbileg et al., (2008) and El-Boshy et al. (2009), who recorded increase in level of IL-1B and IL10 interleukins in brucella infected camels.

Meanwhile, a non significant change in the total leucocytic counts were recorded in buffaloes, cows and sheep infected with brucellosis in comparison with normal animals (Table, 6) this result came in accordance with that reported by Motlelib et al. (1975) in both vaccinated cows and calves and with El-Boshy et al. (2009) in Brucella infected camels. Benjamin (1995) partly explained that differential leucocytic count revealed increase in number of monocytes attributed to the presence of tissue debris in the uterus, as natural uterine cleaning become damped due to retention of placenta in brucellosis where monocytes acted as scavengers in such cases.

In conclusion, brucellosis in buffaloes, cows and sheep causes a dangerous economical problem which was manifested by a wide variety in biochemical and hematological disturbances, therefore strict epidemiological control of brucellosis should be adopted by application of tests 
Some Biochemical And Haematological Studies In ...

and slaughter program for early diagnosis of infected cases and get ride of them, in parallel with sanitary management for elimination of the infection from the farm as well as vaccination program must be accurately followed for healthy young animals.

\section{ACKNOWLEDGMENT}

The authors wish to express the deepest thanks and gratitude to Prof. Dr. Magda S.Shabana, Prof. of Biochemistry, Biochemistry Dept., Animal Health Research Institute, for useful help in accomplishing this study.

Table (2): Serological results of 351 non-vaccinated buffaloes from known Brucella infected herd in Sharkia. The standard CFT results are compared with other tests. A number of 115 buffaloes were definitely positive.

\begin{tabular}{|c|c|c|c|c|c|c|c|c|c|}
\hline \multirow{2}{*}{\multicolumn{3}{|c|}{ CFT }} & \multicolumn{7}{|c|}{ Other serological tests } \\
\hline & & & \multicolumn{3}{|c|}{ SAT } & \multicolumn{2}{|c|}{ BAPAT } & \multicolumn{2}{|c|}{ RBPT } \\
\hline Category & & Animal \# & - & \pm & + & - & + & - & + \\
\hline$\overline{\mathrm{IUU} / \mathrm{ml}<12.5}$ & - & 234 & 221 & 10 & $\overline{3}$ & 2223 & 11 & 2233 & $\overline{1}$ \\
\hline $12.5 \leq \mathrm{IU} / \mathrm{ml}<25$ & \pm & 2 & 0 & 2 & 0 & 0 & 2 & 2 & 0 \\
\hline $\mathrm{IU} / \mathrm{ml} \geq 25$ & + & 115 & 7 & 5 & 103 & 0 & 115 & 1 & 114 \\
\hline \multicolumn{2}{|l|}{ Total } & 351 & 228 & 17 & 106 & 2223 & 128 & 236 & 1115 \\
\hline
\end{tabular}

Table (3): Serological results of selected 149 non-vaccinated cows from known Brucella infected herd in Sharkia. The standard CFT results are compared with other tests. A total of 122 cows were definitely positive.

\begin{tabular}{|c|c|c|c|c|c|c|c|c|c|}
\hline \multirow{2}{*}{\multicolumn{3}{|c|}{ CFT }} & \multicolumn{7}{|c|}{ Other serological tests } \\
\hline & & & \multicolumn{3}{|c|}{ SAT } & \multicolumn{2}{|c|}{ BAPAT } & \multicolumn{2}{|c|}{ RBPT } \\
\hline \multicolumn{2}{|l|}{ Category } & Animal \# & - & \pm & + & - & + & - & + \\
\hline IUU/ml<12.5 & - & 25 & 22 & 3 & 0 & 20 & 5 & 24 & 1 \\
\hline $12.5 \leq \mathrm{IU} / \mathrm{ml}<25$ & \pm & 2 & 1 & 1 & 0 & 0 & 2 & 1 & 1 \\
\hline $\mathrm{IU} / \mathrm{ml} \geq 25$ & + & 122 & 8 & 11 & 103 & 1 & 121 & 10 & 112 \\
\hline \multicolumn{2}{|l|}{ Total } & 149 & 31 & 15 & 103 & 21 & 128 & 35 & 114 \\
\hline
\end{tabular}


Aida, M. Amin et al.,

Table (4): Serological results of 551 non-vaccinated sheep from known Brucella infected flock in Sharkia. The CFT results are compared with other tests. A number of $\mathbf{1 0 4}$ sheep were definitely positive.

\begin{tabular}{|c|c|c|c|c|c|c|c|c|c|}
\hline \multirow{2}{*}{\multicolumn{3}{|c|}{ CFT }} & \multicolumn{7}{|c|}{ Other serological tests } \\
\hline & & & \multicolumn{3}{|c|}{ SAT } & \multicolumn{2}{|c|}{ BAPAT } & \multicolumn{2}{|c|}{ RBPT } \\
\hline \multicolumn{2}{|l|}{ Category } & Animal \# & - & \pm & + & - & + & - & + \\
\hline $\mathrm{IU} / \mathrm{ml}<12.5$ & - & 439 & 429 & 10 & 0 & 416 & 23 & 436 & 3 \\
\hline $12.5 \leq \mathrm{IU} / \mathrm{ml}<25$ & \pm & 8 & 7 & 1 & 0 & 6 & 2 & 7 & 1 \\
\hline $\mathrm{IU} / \mathrm{ml} \geq 25$ & + & 104 & 40 & 7 & 57 & 4 & 100 & 28 & 76 \\
\hline \multicolumn{2}{|l|}{ Total } & 551 & 476 & 18 & 57 & 426 & 125 & 471 & 80 \\
\hline \multirow{4}{*}{\multicolumn{3}{|c|}{$\begin{array}{lll}\text { CFT } & : & \text { Complement fixation test } \\
\text { SAT } & : & \text { Standard agglutination test } \\
\text { RBPT } & : & \text { Brucellosis card test (Rose Bengal test) } \\
\pm & : & \text { Number of suspicious animals }\end{array}$}} & \multicolumn{3}{|c|}{$\mathrm{IU} / \mathrm{ml}$} & \multicolumn{4}{|c|}{ International CFT units per ml of sample } \\
\hline & & & & \multicolumn{2}{|c|}{ BAPAT } & \multicolumn{4}{|c|}{ Buffered acidified plate antigen test } \\
\hline & & & & \multicolumn{2}{|l|}{ - } & \multicolumn{4}{|c|}{ Number of negative animals } \\
\hline & & & & \multicolumn{2}{|c|}{+} & \multicolumn{4}{|c|}{ Number of positive animals } \\
\hline
\end{tabular}

Table (5): Effect of brucellosis on blood biochemical constituents of buffaloes, cows and sheep in Sharkia governorate.

\begin{tabular}{|c|c|c|c|c|c|c|}
\hline \multirow[b]{2}{*}{ Parameters } & \multicolumn{2}{|c|}{ Buffaloes } & \multicolumn{2}{|c|}{ Cows } & \multicolumn{2}{|c|}{ Sheep } \\
\hline & Infected & Control & Infected & Control & Infected & Control \\
\hline Total proteins $(\mathrm{gm} / \mathrm{dL})$ & $\begin{array}{c}6.65 \pm \\
0.17 * *\end{array}$ & $\begin{array}{c}9.25 \pm \\
0.24\end{array}$ & $\begin{array}{c}6.96 \pm \\
0.11 * *\end{array}$ & $\begin{array}{c}8.39 \pm \\
0.21\end{array}$ & $\begin{array}{c}5.50 \pm \\
0.16 * *\end{array}$ & $\begin{array}{c}8.21 \pm \\
0.10\end{array}$ \\
\hline AST (IU/L) & $\begin{array}{c}47.33 \pm \\
1.66 * *\end{array}$ & $\begin{array}{c}34.33 \pm \\
1.09\end{array}$ & $\begin{array}{c}67.39 \pm \\
2.3 * *\end{array}$ & $\begin{array}{c}47.50 \pm \\
0.40\end{array}$ & $\begin{array}{c}73.50 \pm \\
1.02 * *\end{array}$ & $\begin{array}{c}63.60 \pm \\
1.11\end{array}$ \\
\hline ALT (IU/L) & $\begin{array}{c}50.66 \pm \\
0.20 * *\end{array}$ & $\begin{array}{c}43.2 \pm \\
0.50\end{array}$ & $\begin{array}{c}40.75 \pm \\
1.10^{* *}\end{array}$ & $\begin{array}{c}25.20 \pm \\
1.13\end{array}$ & $\begin{array}{c}33.40 \pm \\
1.3 * *\end{array}$ & $\begin{array}{c}23.60 \pm \\
1.40\end{array}$ \\
\hline Glucose (mg/dL) & $\begin{array}{c}77.68 \pm \\
1.69 *\end{array}$ & $\begin{array}{c}87.0 \pm \\
2.11\end{array}$ & $\begin{array}{c}65.59 \pm \\
3.31 *\end{array}$ & $\begin{array}{c}87.22 \pm \\
3.45\end{array}$ & $\begin{array}{l}63.5 \pm \\
1.69 *\end{array}$ & $\begin{array}{c}75.75 \pm \\
1.41\end{array}$ \\
\hline Urea $(\mathrm{mg} / \mathrm{dl})$ & $\begin{array}{c}28.96 \pm \\
0.30 * *\end{array}$ & $\begin{array}{c}23.39 \pm \\
0.84\end{array}$ & $\begin{array}{c}29.25 \pm \\
1.34 * *\end{array}$ & $\begin{array}{c}21.13 \pm \\
1.25\end{array}$ & $\begin{array}{c}29.78 \pm \\
0.52 * *\end{array}$ & $\begin{array}{c}26.37 \pm \\
0.43\end{array}$ \\
\hline Calcium (mg/dL) & $\begin{array}{c}9.52 \pm \\
0.20\end{array}$ & $\begin{array}{c}10.70 \pm \\
0.40\end{array}$ & $\begin{array}{c}8.50 \pm \\
0.38\end{array}$ & $\begin{array}{c}10.27 \pm \\
0.54\end{array}$ & $\begin{array}{c}7.63 \pm \\
0.38\end{array}$ & $\begin{array}{c}9.90 \pm \\
0.54\end{array}$ \\
\hline Inorganic phosphorus (mg/dL) & $\begin{array}{c}6.33 \pm \\
0.50\end{array}$ & $\begin{array}{c}7.50 \pm \\
0.20\end{array}$ & $\begin{array}{c}4.63 \pm \\
0.60\end{array}$ & $\begin{array}{c}6.40 \pm \\
0.45\end{array}$ & $\begin{array}{c}5.12 \pm \\
0.34\end{array}$ & $\begin{array}{c}6.82 \pm \\
0.42\end{array}$ \\
\hline Iron (ug/100 ml) & $\begin{array}{c}179.50 \pm \\
13.50\end{array}$ & $\begin{array}{c}226.35 \\
\pm 5.70\end{array}$ & $\begin{array}{c}71.18 \pm \\
1.60 *\end{array}$ & $\begin{array}{c}80.67 \pm \\
2.00\end{array}$ & $\begin{array}{c}108.60 \pm \\
4.90\end{array}$ & $\begin{array}{c}128.98 \pm \\
4.10\end{array}$ \\
\hline
\end{tabular}

Kafrelsheikh Vet. Med. J. Vol. 7 No. 1 (2009) 
Some Biochemical And Haematological Studies In ...

Table (6): Mean values of haematological picture in brucella-infected and normal buffaloes, cows and sheep in Sharkia Governorate.

\begin{tabular}{|c|c|c|c|c|c|c|}
\hline \multirow{2}{*}{ Parameters } & \multicolumn{2}{|c|}{ Buffaloes } & \multicolumn{2}{|c|}{ Cows } & \multicolumn{2}{|c|}{ Sheep } \\
\hline & Infected & Control & Infected & Control & Infected & Control \\
\hline $\operatorname{RBCs}\left(\mathrm{x} 10^{6} / \mathrm{cm}^{3}\right)$ & $\begin{array}{c}5.89 \pm \\
0.21\end{array}$ & $\begin{array}{r}6.98 \\
\pm 0.12\end{array}$ & $\begin{array}{l}8.90 \pm \\
0.31 *\end{array}$ & $\begin{array}{c}10.65 \pm \\
0.21\end{array}$ & $\begin{array}{c}9.84 \pm \\
0.29\end{array}$ & $\begin{array}{c}11.30 \pm \\
0.50\end{array}$ \\
\hline $\mathrm{Hb}(\mathrm{gm} / \mathrm{dl})$ & $\begin{array}{c}10.55 \pm \\
0.24 *\end{array}$ & $\begin{array}{c}12.89 \pm \\
0.59\end{array}$ & $\begin{array}{l}8.90 \pm \\
0.21 *\end{array}$ & $\begin{array}{c}10.66 \pm \\
0.20\end{array}$ & $\begin{array}{l}10.83 \pm \\
0.30^{*}\end{array}$ & $\begin{array}{c}12.00 \pm \\
0.28\end{array}$ \\
\hline $\mathrm{PCV}(\%)$ & $\begin{array}{c}36.32 \pm \\
0.18 *\end{array}$ & $\begin{array}{c}37.98 \pm \\
0.34\end{array}$ & $\begin{array}{c}38.23 \pm \\
0.20^{*}\end{array}$ & $\begin{array}{c}39.05 \pm \\
0.10\end{array}$ & $\begin{array}{c}23.06 \pm \\
0.39^{*}\end{array}$ & $\begin{array}{c}24.81 \pm \\
0.15\end{array}$ \\
\hline WBCs $\left(\times 10^{3} / \mathrm{cm}^{3}\right)$ & $\begin{array}{c}7.38 \pm \\
0.48\end{array}$ & $\begin{array}{c}5.39 \pm \\
0.38\end{array}$ & $\begin{array}{c}7.35 \pm \\
0.54\end{array}$ & $\begin{array}{c}5.45 \pm \\
0.31\end{array}$ & $\begin{array}{c}9.12 \pm \\
0.57\end{array}$ & $\begin{array}{c}6.79 \pm \\
0.51\end{array}$ \\
\hline
\end{tabular}

* Significant $(\mathrm{P}<0.05)$

** Highly significant $(\mathrm{P}<0.001)$

\pm Standard error (SE)

\section{REFERENCES}

- Abu-Damir,H.;Tageldin, M.H.; Kenyon, S.J. and Idris, O.F. (1989): "Ioslation of Brucella abortus from experimentally infected dromedary camels in Sudan: a preliminary report." Vet. Res. Comm., 13: 403-406.

- Alton, G.G.; Jones, L.M.; Angus, R.D. and Verger, J.M. (1988): "Techniques for the Brucellosis laboratory." INRA, 65006, Paris, France.

- Benjamin, M.M. (1995): "Outline of Veterinary clinical pathology." $4^{\text {th }}$ Ed., Kalyani Publishers, New Delhi.

- Cloeckaert,A.;Grayon,M.;Grepunet,O.and Boumedine, K.S. (2003): "Clasification of Brucella strains isolated from marine mammals by infrequent restriction site- PCR and development of specific PCR identification tests." Microbes Infect. 5 (7): 593- 602.

- Coles, E.H. (1986): "Veterinary Clinical Pathology." $4^{\text {th }}$ Ed., W.B. Saunders Company, Philadelphia, London, Toronto. 
- Crosby, E.; Liosa, L.; Miro Quesado, M.; Carillo, P. and Gotuzzo, E. (1984): "Haematological changes in brucellosis." J. Infect. Disease., 150: 419-424.

- Duncan, J.R. and Prasse, K.W. (1986): "Veterinary Laboratory Medicine." $2^{\text {nd }}$ Ed., Iowa State Univ. Press, Ames, Iowa.

- Edward, J.Y. (1997): "Human brucellosis pathology and response to therapy." $50^{\text {th }}$ Ed., Anniversary Meeting of Brucellosis Research Conference, Chicago.

- El-Boshy, M.; Abbas, H.; El-Khodery, S. and Osman, S. (2009): "Cytokine response and clinicopathological findings in Brucella infected camels (Camelus dromedaries)." Veterinarni Medicina, 54 (1): 25-32.

- El-Diasty, M.M. (2004): "Epizootiological and immunological studies on bovine brucellosis." M.V.Sc. thesis, Infectious diseases, Faculty Vet. Med., Suez Canal University.

- El-Sawalhy,A.A.; Montasser,A.M.and Rizk,L.G. (1996): "Diagnostic and biochemical evaluation of camel brucellosis." Vet. Med. J. Giza, 44: 323-329.

- Enany, M.; Magda, S. Shabana and Sohair, Y. Mohamed (1997): "Bacteriological, biochemical and histopathological studies in brucella infected cattle and sheep in Suez Canal area." Benha Vet. Med. J., 8 (2): 93-110.

- Erdogan, S.; Celik, S.; Aslantas, O.; Kontas, T. and Ocak, S. (2007): "Elevated C.AMP levels reverse Brucella mellitensis-induced lipid peroxidation and stimulate IL-10 transcription in rats." Res. Vet. Sci., 82: 181-186. 
- Fahmy, B.G.A. and Hoda, M. Zaki (2006): "Serological tests and biochemical profiles in camels infected with brucellosis." Vet. Med. J., Giza, 54 (2): 379-403.

- Forbes, L.B.; Tessara, S.V. and Lees, W. (1996): "Experimental studies on Brucella abortus in moose (Alce alcesi)." J. Wild L. Dis., 32-94.

- FAO "Food and Agriculture Organization of the United Nations" (2003): "Brucellosis (bovine) available at http: //WWW. Sp. Int/ Rahs/ Mannual/ Bovine/ Brucellosis." HTM. Accessed 4 Jun $2007 .$.

- Glinder, E.M. and King, J.D. (1972): "Rapid colorimetric determination of calcium in biological fluids." Am. J. Clin. Path., 58: 378-382.

- Helal, A.D. and Abdel Fattah, Sh.M. (2003): "Biochemical, electron microscopical and immunotoxicological studies on Brucella infected and /or vaccinated sheep." Egypt. J. Agric. Res., 81 (1): 2003.

- Helal, A.D.; Abdel Fattah, Sh.M. and Shehata, F.E. (2004): "Some serum biochemical, hormonal and protein electrophoretic studies on sheep and goat suffering from mycotxoicosis and/or brucellosis." Egypt. J. Agric. Sci., 82 (3): 1483-1498.

- Hend Ibrahim, M.A. (2004): "Studies on sensitivity and specificity of some serological tests used for diagnosis of brucellosis in cattle." M.V.Sc.thesis,Infectious Diseases, Fac.Vet. Med., Beni Suef University.

- Henry, R.J.; Cannon, D.C. and Wikelman, J.W. (1974): "Clinical chemistry, principles and Techniques." pp. 437-440, Harpel and Row, Hagerstown, M.D., USA.

- Hosein, H.I.; El-Sheary, M.N. and Ibrahim, K.M. (1999): "Evaluation of immunoblotting analysis for detection of brucella infection." $1^{\text {st }}$ Sci. Conf., Fac. Vet. Med., Beni Suef, 9 (3B). 
- Hosein, M.I.; Sohair, Y.; Enany, M. and Global, M.A. (2001): "The role of some brucella carriers in maintenance of brucella infection." Beni-Suef Vet. Med. J., XI (2): 521-528.

- Jurado, R.L. (1997): "Iron, infectious and anaemia of inflammation." Clin. Infect. Dis., 25: 888-895.

- Merck Veterinary Manual (2003): "Brucellosis in cattle contagious abortion, Bang's diseased Available at : http: //WWW. Merck Vetmanual. Com/ MVM/ index. JSP? Cfile $=\mathrm{htm} / \mathrm{Be} / 110502$. htm. Accessed 4 June 2007."

- Montaser,A.M.(1995): "Morphopathological and immunopathological studies on animal naturally and experimentally infected by brucella." Ph.D. Thesis, Pathology Dept., Fac. Vet. Med., Cairo University.

- Montaser, A.M.; Hamdy, M.E.; El-Biomy, E.M. and Khoudier, R. (2001): "Bacteriological profile of brucella isolated from cattle in Egypt." $6^{\text {th }}$ Sci. Conf., Egyptian Society for Cattle Diseases, 4-6 Nov., 163-170.

- Mottelib, A.A.; Sayour, E.M.; Samira, El-Gibaly and El-Allawy, T.A.A. (1975): "Changes in the blood picture of cattle and calves following vaccination with Brucella abortus (strain 45/20) vaccine." Zbl. Vet. Med., 22: 381-385.

- Nada, A.R.; Shalaby, S.I.A. and Ahmed, W.M. (1992): "Minerals and trace elements blood profile of brucella infected, pregnant and non pregnant animals." Egypt. J. Comp. Path. Clin. Pathol., 5 (2): 203-213.

- Nielsen, K.H. (2002): "Diagnosis of brucellosis by serology." Vet. Microbiol., 90: 447-459. 
- Odbileg, R.; Purevtseren, B.; Gantseteg, D.; Boldbaatar, B.; Buyannemekh, T.; Galmandakh, Z.; Erdenebaatar, J.; Konnai, S.; Onuma, M. And Ohashi, K. (2008): "Cytokine responses in camels (Camelus bacterianus) vaccinated with Brucella abortus strain 19 vaccine." J. Vet. Med. Sci., 70: 197-201.

- OIE (2008): "Bovine brucellosis." Chapter 2.4.3., "Caprine and ovine brucellosis, excluding (Brucella ovis)." Chapter 2.7.2., OIE terrestrial Manual OIE Publication, Paris.

- Omaima, M.M.; Kamla, El- Saied; Abbas, H.E. and Soliman, T.M. (2003): "Some biochemical studied on clinically healthy and Brucella infected camels." Egypt. J. Basic and Appl. Physiol. 2 (1): 121- 127.

- Pappas, G.;Panagopoulou, P.; Christou, L.; and Akritidis, N. (2006): "Brucella as a biological weapon." Cell Mol Life Sci 63 (12- 20): 22292236.

- Pasquinelli, F. (1979): "Diagnostica et techniche di laboratorio." Rosini, Firenze, 1070.

- Patton, C.J.and Crouch,S.R.(1977): "Spectrophotometer investigation of urea." Anal Chem., 49: 464-469.

- Radostits, O.M.; Gay, C.C.; Hinchclift, K.W. and Constable, P.D. (2007): "Veterinary Medicine, A textbook of the diseases of cattle, sheep, pigs, goats and horses." $10^{\text {th }}$ Ed., W.B. Saunders Co., London Toronto, ISBN-10: 0702027774.

- Reitman, S. and Frankel, S. (1957): “A colorimetric determination of serum glutamic oxaloacetic and glutamic pyruvic transaminase." Am. J. Clin. Path., 28:56-58. 
- Sauert, J.M. and Vilissova, N. (2002): "Human brucellosis." J. Am. Board Fam Pract. 15: 401- 406.

- Schalm, O.W. (2000): "Veterinary Haematology." $5^{\text {th }}$ Ed., Bernard, V.; Feldman Joseph, G.; Zinkl, Nemi C. Jain, Lippincot Williams and Wilkins, printed in Canada

- SPSS 14 (2006): "Statistical Package for Social Science, SPSS for windows Release 14.0.0, 12 June, 2006." Standard Version, Copyright SPSS Inc., 1989-2006, All Rights Reserved, Copyright ® SPSS Inc.

- Stevens, M.G. and Olsen, S.C. (1994): "In vitro effects of live and killed Brucella abortus on bovine cytokine and prostaglandin E2 production." Vet. Immuol. And Immunopathol., 40: 149-161.

- Thompson, R.B. (1980): "A short textbook of hematology." $5^{\text {th }}$ Ed., English Language Book Society and Pitman Medical Publishers Inc., Chicago.

- Tizard,I.(1992): "Veterinary Immunology." Philadelphia W.B. Saunders, p. $41,4^{\text {th }} \mathrm{Ed}$.

- Trinder, P. (1969): "Determination of glucose in body fluids." Ann. Clin. Biochem., 6: 24-34.

- Varely, H. (1976): "Practical Clinical; Biochemistry." $4^{\text {th }}$ Ed., Arnold Heimemann, New Delhi

- Waner, T. and Harrus, Sh. (2000): "Anaemia of inflammatory disease." Scham 2000, Chapter 35, pp. 205-209. 


\section{بعض الدراسات البيوكيميائية والهيماتولوجية في الجاموس والأبقار والأغنام المصابة بالبروسيلا

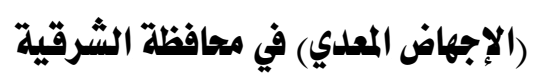

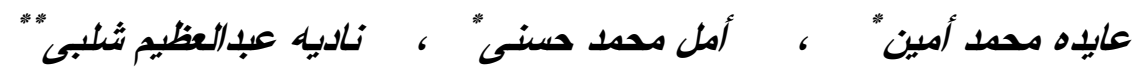

$$
\text { " ق قسم الكيمياء - معها بحوث صحة الحيوان - الدقى البروسيلا - معهل بحوث صحة الحيوان - الدقى }
$$

أجريت هذه الدراسة على 351 من الجاموس، 149 من الأبقار ، 551 من الأغنام من مزرعة بمنطقة الصالحية الجديدة بمحافظة الثرقية. وقد تم الفحص السيرولوجى لهذه الحيوانات لتحديد الحالات المصابة بمرض الإجهاض المعدي وذلك باستخدام أختبار الأنتيجين المخد المحمض الثريحى و الروز بنجال و التلزن الأنبوبى ومثبت المكمل ولأجر اء الفحص البيوكيمائى و الهيماتولوجى قمنا بتجميع عدد 60 عينة من الحالات الأيجابية (20 من كل نوع) بالأضافة الى 60 عينة من الحالات السالبة (20 من كل نوع). أوضحت النتائج وجود زيادة معنوية فى النشاط الأنزيمى لكل من الأسبارتيت أمينوتر انسفيريز و الألانين أمينو نرانسفيريز ومستوى اليوريا فى الأنواع الثلاثة كما تم

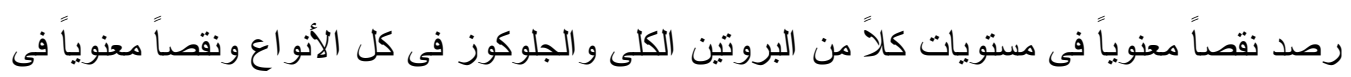
مستوى الحديد فى حالة الأبقار المصابة فقط.

لم يظهر الفحص الكيميائى أى تغيرات فى مسنويات كلا من الكالسيوم والفوسفور الغير عضوى للأنواع الثلاثة مقارنة بالمجموعات الضابطة. بينما أظهر الفحص الهيمانولوجى نقصاً معنوياً فى تركيز الهيموجلوبين و الهيماتوكريت (PCV) لكل الأنو اع محل الدراسة مصحوباً بنقص فى عدد كرات الدم الحمر اء ذو أثز معنوى فى حالة الأبقار المصابة فقط بينما أظهر الفحص عدم تأثر العدد الكلى لكر ات الدم البيضاء فى الأنواع الثلاثة المصابة مقارنة بالمجموعات الضابطة. 